\title{
The Chloroplast Genome of Lilium henrici: Genome Structure and Comparative Analysis
}

\author{
Hai-Ying Liu, Yan Yu, Yi-Qi Deng, Juan Li, Zi-Xuan Huang and Song-Dong Zhou * \\ Key Laboratory of Bio-Resource and Eco-Environment of Ministry of Education, College of Life Sciences, \\ Sichuan University, Chengdu 610065, China; lhy921180@163.com (H.-Y.L.); yyu@scu.edu.cn (Y.Y.); \\ yiqiden@gmail.com (Y.-Q.D.); lijuanxxn@163.com (J.L.); newshirley277@163.com (Z.-X.H.) \\ * Correspondence: zsd@scu.edu.cn; Tel.: +86-85415006
}

Received: 11 April 2018; Accepted: 18 May 2018; Published: 26 May 2018

\begin{abstract}
Lilium henrici Franchet, which belongs to the family Liliaceae, is an endangered plant native to China. The wild populations of $L$. henrici have been largely reduced by habitat degradation or loss. In our study, we determined the whole chloroplast genome sequence for L. henrici and compared its structure with other Lilium (including Nomocharis) species. The chloroplast genome of $L$. henrici is a circular structure and $152,784 \mathrm{bp}$ in length. The large single copy and small single copy is $82,429 \mathrm{bp}$ and $17,533 \mathrm{bp}$ in size, respectively, and the inverted repeats are $26,411 \mathrm{bp}$ in size. The L. henrici chloroplast genome contains 116 different genes, including 78 protein coding genes, 30 tRNA genes, 4 rRNA genes, and 4 pseudogenes. There were 51 SSRs detected in the L. henrici chloroplast genome sequence. Genic comparison among L. henrici with other Lilium (including Nomocharis) chloroplast genomes shows that the sequence lengths and gene contents show little variation, the only differences being in three pseudogenes. Phylogenetic analysis revealed that $N$. pardanthina was a sister species to L. henrici. Overall, this study, providing L. henrici genomic resources and the comparative analysis of Lilium chloroplast genomes, will be beneficial for the evolutionary study and phylogenetic reconstruction of the genus Lilium, molecular barcoding in population genetics.
\end{abstract}

Keywords: Liliaceae; Lilium henrici; chloroplast genome; comparative analysis; phylogeny

\section{Introduction}

The genus Lilium L., including about 115 species, is mainly distributed throughout cold and temperate regions of the Northern Hemisphere [1]. Many species of this genus have horticultural and food uses [2], especially their ornamental value. Lilies, the plants in the genus Lilium, has been widely known as one of the most important cut flowers in the world during the last 50 years [3]. Many Lilium species have large and beautiful flowers, with showy color and fragrant smell, and horticulturists produce many garden cultivars by interspecific hybridization according to their characteristics. China is rich in wild Lilium resources and possesses many endemic species. These rare Lilium species are a valuable raw material for hybrid breeding. In the traditional classification, species of Lilium have been divided into seven sections [4] using 15 morphological characters and many researchers have revised this classification. Currently, many molecular phylogenetic and morphological analysis inform our understating of this genus [5-13]. However, species-level relationships in Lilium are not yet clear [14] and more effective molecular markers are needed to determine interspecific phylogeny more accurately.

Lilium henrici Franchet, a Lilium species considered to be closely related to the Nomocharis, grows naturally in forests at an elevation of $2800 \mathrm{~m}$ in China's Sichuan and Yunnan provinces [1]. It has a unique flower morphology and high horticultural value. However, the enormous economic value of 
Lilium plants for ornamental purposes, and as foods and medicines has led to excessive exploitation, causing their habitat to be fragmented $[15,16]$, and unfortunately, many Lilium species, including L. henrici. were classified as endangered in the 2013 report and the impact of habitat degradation or loss has resulted in population decline.

The typical chloroplast genomes of angiosperms usually encode 120 to 130 genes and are between 120 and $170 \mathrm{~kb}$ in length [17]. They are covalently closed molecules consisting of four parts, which are a large single copy (LSC) region, a small single copy (SSC) region, and a pair of inverted repeats (IRs) regions. As a consequence of conserved gene content and structure [18], the availability of plastome DNA sequences, an ability to resolve relationships at lower taxonomic levels [19], and maternal inheritance, the chloroplast genome has become particularly useful in phylogenetic and population genetic studies [20].

Advances in next generation sequencing technologies have revolutionized whole genome sequencing. The development of NGS methods achieve a breakthrough in sequencing technology and provide researchers with faster and cheaper methods to acquire chloroplast genome data [21]. More and more chloroplast genomic sequences are being analyzed, and phylogenetics have entered a new era at the same time. The chloroplast genome sequence of L. henrici obtained in this study can raise our awareness of this species, and the results will enrich the genetic information of the genus Lilium we already have, providing a theoretical basis for further study on the evolution of Lilium and species identification.

\section{Materials and Methods}

\subsection{Plant Material, DNA Extraction and Sequencing}

We sampled healthy and mature leaves of L. henrici from Danzha County $\left(25^{\circ} 27^{\prime} 39^{\prime \prime} \mathrm{N}, 98^{\circ} 15^{\prime} 27^{\prime \prime} \mathrm{E}\right)$, Yunnan Province, China and preserved them in liquid nitrogen for further study. The corresponding voucher specimens were deposited at Sichuan University Herbarium (SZ Herbarium). Total genomic DNA of L. henrici was extracted from sampled leaves using the Plant Genomic DNA Kit (Tiangen Biotech, Beijing, China) following the manufacturer's instructions. The isolated genomic was manufactured to average 350 bp paired-end(PE) library using Illumina Hiseq platform (Illumina, San Diego, CA, USA), and sequenced by an Illumina genome analyser (Hiseq PE150).

\subsection{Chloroplast Genomic Assembly and Annotation}

We used the software FastQC [22] v0.11.7 to evaluate the quality of sequenced raw reads. After quality assessment, we filtered the chloroplast genome related reads by mapping all the raw reads to the published chloroplast genome sequences in Liliaceae. All related reads were assembled to contigs using SOAPdenovo2 [23], and all contigs were sorted and joined into a single draft sequence with $L$. taliense as the reference in the software Geneious [24] v11.0.4. The gaps and ambiguous sequences were manually adjusted after Sanger sequencing. Annotations of chloroplast genome were conducted by the software Geneious v11.0.4, using other existent Lilium chloroplast genome sequences as references. Star/stop codons and intron/exon borders were edited manually after comparation with references. In addition, we used tRNAscan-SE [25] v2.0 to verify the identified tRNA genes. The circular map of L. henrici plastid genome was generated utilizing the OGDRAW program [26].

\subsection{Simple Sequence Repeats (SSRs) Analysis}

Perl script MISA [27] was used to detect chloroplast simple sequence repeats in twenty chloroplast genome sequences of Lilium (including Nomocharis). Its parameters were set as follow: the minimum numbers of repeats for mononucleotide, dinucleotides, trinucleotides, tetranucleotides, pentanucleotide and hexanucleotides were 10, 5, 4, 3, 3 and 3, respectively. 


\subsection{Analysis on Codon Usage}

Codon usage of the L. henrici chloroplast genome was analyzed via codonW [28] software. Protein-coding genes (CDS) were filtered from L. henrici chloroplast genome with following conditions to reduce deviation of the results: (1) the length of every CDS must be more than 300 nucleotides [29,30]; (2) Repeat sequences were removed. Finally, 53 CDS in L. henrici were selected for further study (Table S1).

\subsection{Genome Comparision}

We downloaded Lilium and Nomocharis pardanthina [14,31-39] chloroplast genome sequences from GenBank and compared different chloroplast genomes in genus Lilium, including L. superbum (NC_026787), L. longiflorum (KC968977), L. distichum (NC_029937), L. tsingtauense (KU230438), L. hansonii (NC_027674), L. cernuum (NC_034840), L. fargesii (NC_033908), L. taliense (NC_034370), L. bakerianum (NC_035592), L. brownie (NC_035588), L. duchartrei (NC_035591), L. henryi (NC_035570), L. lancifolium (NC_035589), L. leucanthum (NC035590), L. primulinum var. ochraceum (KY748298), and L. amabile (NC_035988), L. callosum (NC_035989), L. philadelphicum (NC_035990). The mVISTA [40] program was used to compare L. henrici chloroplast genome sequence with other Lilium chloroplast genome sequences with Shuffle-LAGAN model, in which the annotation of L. longiflorum as the reference. We compared the borders between single copy regions (LSC and SSC) and inverted repeats (IR) regions among twenty Lilium (including Nomocharis) chloroplast genome sequences by using Geneious v11.0.4 software.

\subsection{Lilium Phylogenomic Reconstruction Based on Chloroplast Genome}

Phylogenomic reconstruction of the genus Lilium was based on twenty-five whole chloroplast genome sequences, which were one species of Cardiocrinum, four species of Fritillaria and twenty species of Lilium (including N. pardanthina). All the sequences were aligned by MAFFT [41] and trimmed by trimAl [42]. Sequences, after alignment and trim, were used to select the best substitution model in the program jModelTest v2.1.7 [43] and the best model was GTR + I + G model. The phylogenomic relationship was inferred by maximum-likelihood method based on the GTR + I + G substitution model in MEGA 7.0 [44] with 1000 bootstrap replicates. Species in Cardiocrinum and Fritillaria were selected as outgroups.

\section{Results and Discussion}

\subsection{Chloroplast Genome Features of the L. henrici}

We determined the L. henrici whole chloroplast genome sequence and deposited it to GenBank under accession number: MH136807. The complete plastid genome of L. henrici is a typical quadripartite structure with $152,784 \mathrm{bp}$ in length, near to other Lilium chloroplast genome levels [14,31-39]. The genome, displaying a conserved structure found in most chloroplast genomes of plants $[45,46]$, possesses an LSC region $(82,429 \mathrm{bp})$, an SSC region $(17,533 \mathrm{bp})$ and a pair of IR regions (26,411 bp) (Figure 1, Table 1). In the L. henrici plastid genome, the overall GC content is $37.0 \%$. The GC content of the IR regions $(42.5 \%)$ is higher than that of the overall genome $(37.0 \%)$, LSC region $(34.83 \%)$ and SSC region (30.59\%). A total of 136 genes are detected, 20 of which are duplicated in the IR regions. There were 84 genes for protein-coding, 38 for tRNA, eight for rRNA and six for other functions among the 136 genes (Table 2).

By containing several internal stop codons, the infA, ycf1 (the shorter one), $y c f 15$, and ycf68 were interpreted as pseudogenes in our study. The same phenomenon also appears on other plants [47-50] or infA gene is lost in some taxa [51]. In a previous study, the $y c f 1$ and $y c f 68$ regions were considered to have potential function and required further study [47]. Different from other Lilium species, L. henciri is similar to L. primulinum var. ochraceum in having only has $23 \mathrm{bp}$ duplicated. Other studies revealed only one rps19 gene in Lilium close species, such as species in Amana, Cardiocrinum and Fritillaria [47,52-54]. 
Eighteen distinct genes (six of which are tRNAs) contain introns (Table S2), 3 (rps12, clpP and ycf3) of which contain two introns and the others only have one intron. The gene rps12 is a trans splicing gene with its three exons located in the LSC and IR regions, respectively.

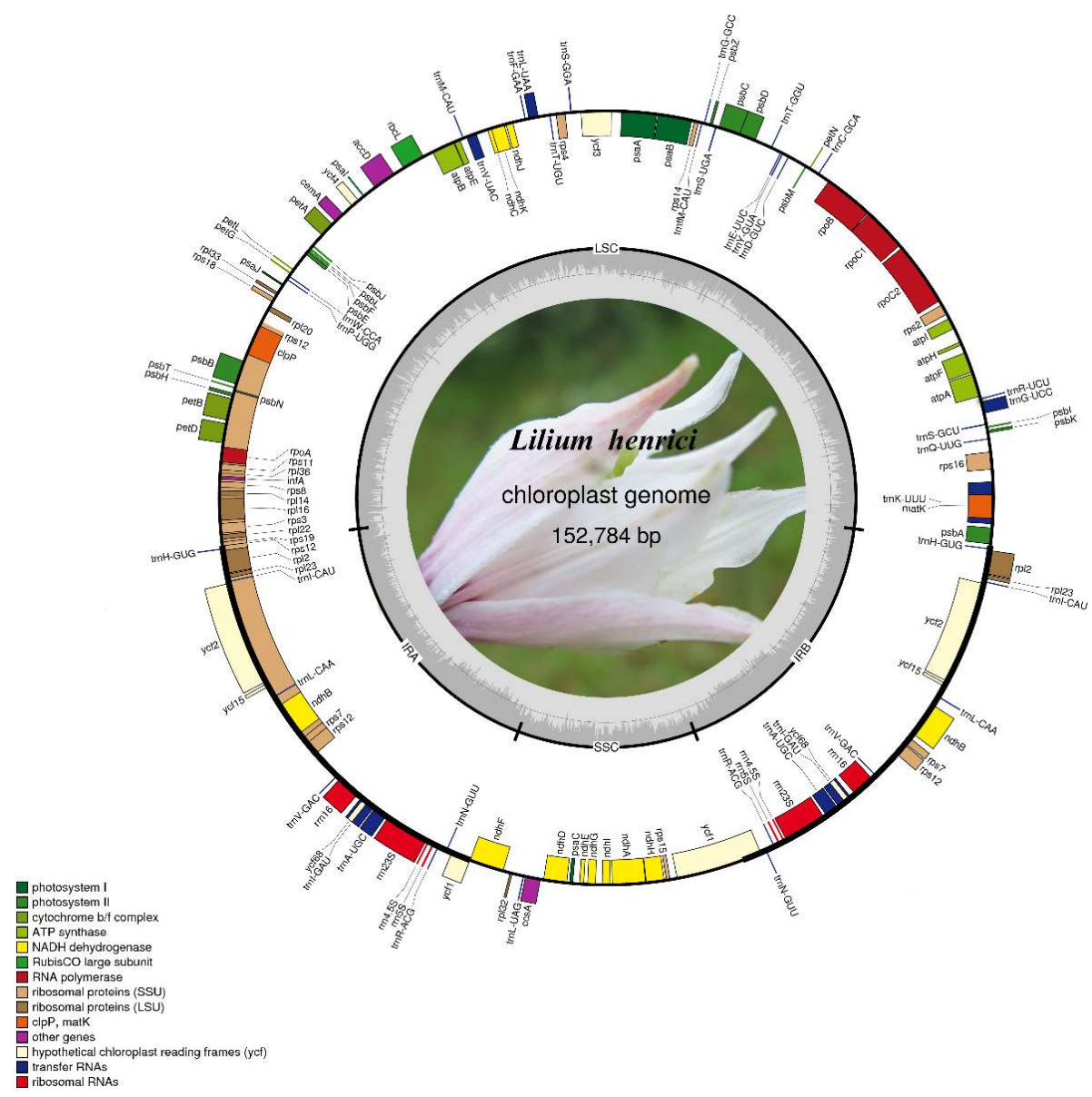

Figure 1. Gene map of the Lilium henrici chloroplast genome. The genes drawn outside and inside the outer circle transcribed clockwise and counter-clockwise, respectively. Genes of different functional groups are color coded. GC content and AT content are represented on the inner circle by darker gray and lighter gray, respectively.

Table 1. Genome features of L. henrici complete chloroplast genome.

\begin{tabular}{cc}
\hline Region & Chloroplast Features \\
\hline Chloroplast genome size (bp) & 152,784 \\
LSC (bp) & 82,429 \\
SSC (bp) & 17,533 \\
IR (bp) & 26,411 \\
Total GC contents (\%) & 37.0 \\
LSC GC contents (\%) & 34.83 \\
SSC GC contents (\%) & 30.59 \\
IR GC contents (\%) & 42.50 \\
No. of total/unique genes & $136 / 116$ \\
Total CDS length (bp) & 113,441 \\
Intergenic spacer (bp) & 39,343 \\
Protein-coding genes & 78 \\
tRNAs & 30 \\
rRNAs & 4 \\
Genes duplicated & 20 \\
Genes with intron(s) & 18 \\
Genes with a single intron & 15 \\
Genes with two introns & 3 \\
tRNAs with intron(s) & 6 \\
\hline
\end{tabular}


Table 2. List of genes present in the L. henrici chloroplast genome.

\begin{tabular}{|c|c|c|c|}
\hline \multicolumn{2}{|c|}{ Classification of Genes } & \multirow{2}{*}{$\begin{array}{c}\text { Name of Gene(s) } \\
r r n 4.5(\times 2), r r n 5(\times 2), r r n 16(\times 2), r r n 23(\times 2)\end{array}$} & \multirow{2}{*}{$\begin{array}{c}\text { Number } \\
8\end{array}$} \\
\hline RNA genes & Ribosomal RNAs & & \\
\hline & Transfer RNAs & 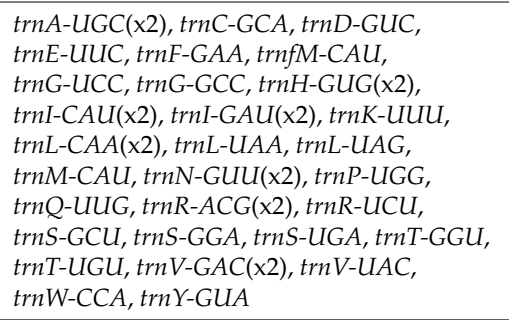 & 38 \\
\hline \multirow[t]{9}{*}{ Protein genes } & Photosynthesis & & \\
\hline & Photosystem I & $p s a A, p s a B, p s a C, p s a I, p s a J$ & 5 \\
\hline & Photosystem II & $\begin{array}{l}p s b A, p s b B, p s b C, p s b D, p s b E, p s b F, p s b H \\
p s b I, p s b J, p s b K, p s b L, p s b M, p s b N, p s b T, p s b Z\end{array}$ & 15 \\
\hline & Cytochrome & pet $A, \operatorname{pet} B, \operatorname{pet} D, \operatorname{pet} G, \operatorname{pet} L, \operatorname{pet} N$ & 6 \\
\hline & ATP synthase & $\operatorname{atp} A, \operatorname{atp} B, \operatorname{atp} E, \operatorname{atp} F, \operatorname{atpH}, \operatorname{atpI}$ & 6 \\
\hline & Rubisco & $r b c L$ & 1 \\
\hline & NADH dehydrogenease & $\begin{array}{l}n d h A, n d h B(\times 2), n d h C, n d h D, n d h E, n d h F \\
n d h G, n d h H, n d h I, n d h J, n d h K\end{array}$ & 12 \\
\hline & $\begin{array}{l}\text { ATP-dependent protease } \\
\text { subunit } \mathrm{P}\end{array}$ & $c l p P$ & 1 \\
\hline & $\begin{array}{l}\text { Chloroplast envelope } \\
\text { membrane protein }\end{array}$ & $\operatorname{cem} A$ & 1 \\
\hline \multirow[t]{2}{*}{ Ribosomal proteins } & large units & $\begin{array}{l}\text { rpl2(x2), rpl14, rpl16, rpl20, rpl22, rpl23(x2), } \\
\text { rpl32, rpl33, rpl36 }\end{array}$ & 11 \\
\hline & small units & $\begin{array}{l}r p s 2, r p s 3, r p s 4, r p s 7(\times 2), r p s 8, r p s 11 \\
r p s 12(\times 2), r p s 14, r p s 15, r p s 16, r p s 18, r p s 19\end{array}$ & 14 \\
\hline \multirow[t]{4}{*}{ Transcription/trnslation } & RNA polymerase & $r p o A, r p o B, r p o C 1, r p o C 2$ & 4 \\
\hline & Miscellaneous proteins & $\operatorname{acc} D, \operatorname{ccs} A$, matK & 3 \\
\hline & $\begin{array}{l}\text { Hypothetical proteins \& } \\
\text { Conserved reading frame }\end{array}$ & $y c f 1, y c f 2(x 2), y c f 3, y c f 4$ & 5 \\
\hline & Pseudogenes & $y c f 15(\mathrm{x} 2), y c f 68(\mathrm{x} 2), \inf A, y c f 1$ & 6 \\
\hline Total & & & 136 \\
\hline
\end{tabular}

\subsection{SSRs Analysis}

Simple sequence repeats (SSRs) usually composed of 1-6 nucleotide units [55], which have been accepted as important molecular markers for population variation studies [56-58]. We used MISA perl script to determine the SSRs loci in the twenty chloroplast genome sequences of Lilium (including Nomocharis) (Figure 2, Table S3). A total of 51 perfect microsatellites were detected in the L. henrici chloroplast genome (Figure 2A, Table S3). Moreover, 46, 44, 46, 43, 47, 44, 48, 66, 52, 52, 43, 56, 48, 54, 52, 45, 49, 48, and 52 SSRs were found in L. amabile, L. bakerianum, L. brownie, L. callosum, L. cernuum, L. distichum, L. duchartrei, L. fargesii, L. hansonii, L. henryi, L. lancifolium, L. leucanthum, L. longiflorum, L. philadelphicum, L. primulinum var. ochraceum, L. superbum, L. taliense, L. tsingtauense, and N. pardanthina (Figure 2A, Table S3). L. fargesii (66 SSRs) and L. callosum (43 SSRs), L. lancifolium (43 SSRs) possess the highest and lowest number of SSRs, respectively. All SSRs are divided into six types of microsatellites, which are mononucleotide, dinucleotide, trinucleotide, tetranucleotide, penta-nucleotide and hexanucleotide (Figure 2A, Figure 2B). The total number of mononucleotide repeats is more than the sum of the other types (Figure 2B) and all mononucleotide repeats consist of A or T bases. In the total SSRs loci, the repeats located in the LSC region is much higher than that in the SSC region and IR regions (Figure 2C). There are nine common SSRs detected in twenty Lilium (including Nomocharis) species (Figure 2D), which are (A)10, (T)15, (TA)5, (GA)5, (TC)5, (TTA)4, (AATT)3, (TTTA)3, and (AATA)3. Among the nine common SSRs, there are differences in the number 
and location of (A)10, (T)15, (TA)5, (TC)5 and (TTTA)3. These types of SSRs might be useful as molecular markers when studying Lilium genetic variability.

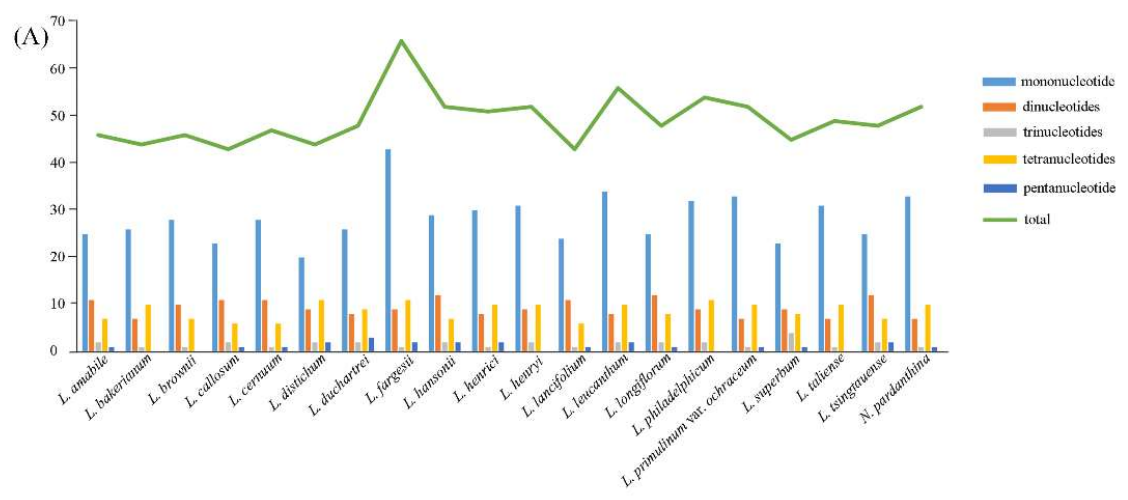

(B)
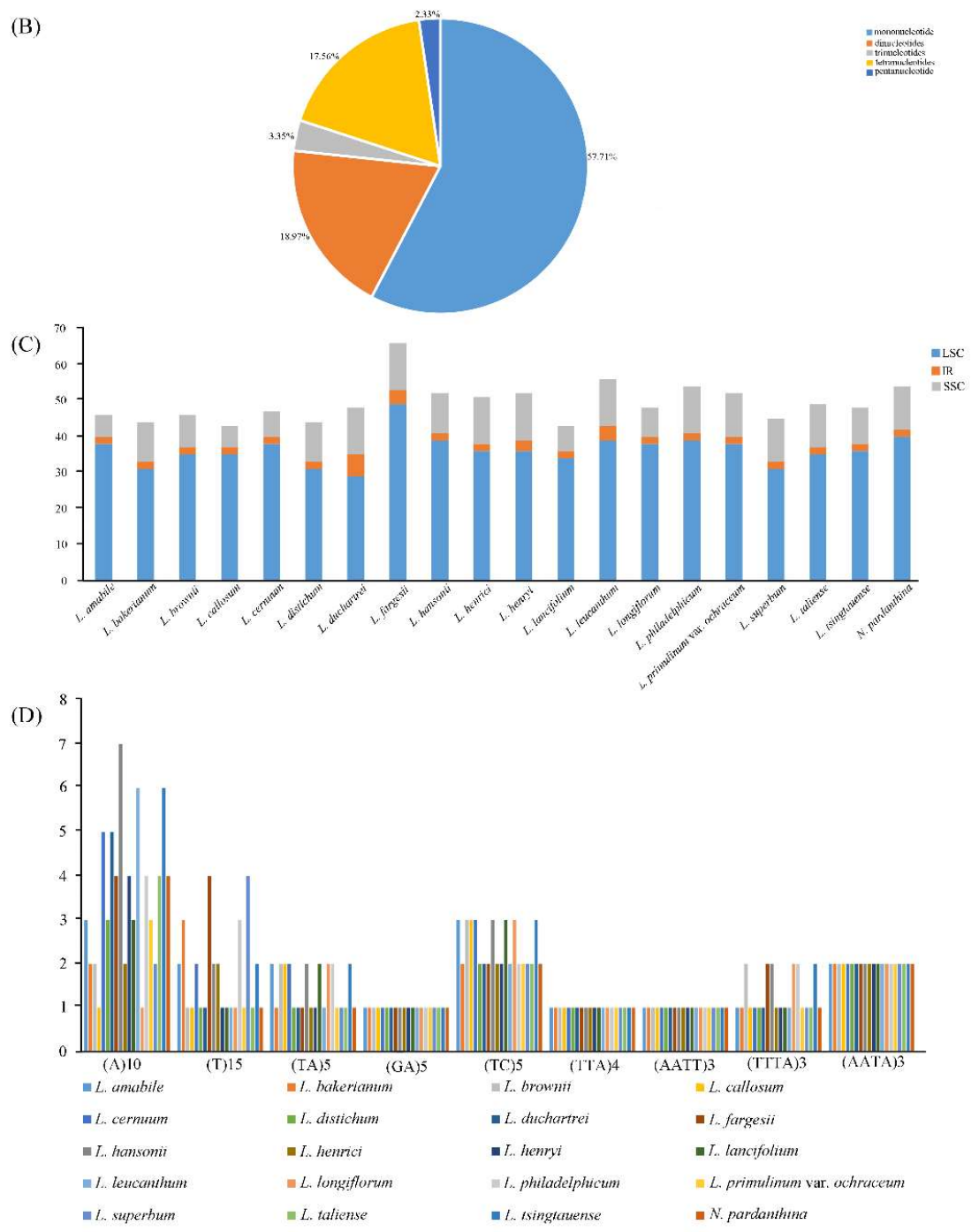

Figure 2. Analysis of simple sequence repeats (SSRs) in twenty Lilium (including Nomocharis) chloroplast genome sequences. (A) Number of different SSRs types detected in twenty Lilium (including Nomocharis) chloroplast genome sequences; (B) Presence of different SSRs types in all SSRs of twenty Lilium (including Nomocharis) chloroplast genome sequences; (C) Number of SSRs in the LSC, IR, SSC regions in twenty Lilium (including Nomocharis) chloroplast genome sequences; (D) Number of common SSRs in twenty Lilium (including Nomocharis) chloroplast genome sequences. 


\subsection{Codon Usage Analysis}

We used 53 protein coding sequences from the L. henrici chloroplast genome for codon usage analysis. All protein coding sequences contain 21324 codons (Table 3). Leucine (2184 codons, approximately $10.24 \%$ of the total) and cysteine (241 codons, approximately $1.13 \%$ of the total) are the highest and lowest number of amino acids, respectively. Moreover, Met and Trp are encoded by only one codon. Except these two amino acids, others have obvious codon usage bias. For example, synonymous codons GCU, GCC, GCA and GCG encode alanine and the corresponding Relative Synonymous Codon Usage (RSCU) values [59] for these four codons in L. henrici are 1.75, 0.63, 1.16 and 0.47 , respectively. There are 32 codons with a RSCU value more than 1 . CDS GC content, about $37.4 \%$, is similar with genome-wide GC content (37.0\%). Codon usage bias of chloroplast genome may be affected by selection and mutation [60], and research on codon preferences can help us to better understand the exogenous gene expression and molecular evolution mechanisms of L. henrici.

Table 3. Codon usage for L. henrici chloroplast genome.

\begin{tabular}{|c|c|c|c|c|c|c|c|}
\hline Amino Acid & Codon & Number & RSCU & Amino Acid & Codon & Number & RSCU \\
\hline \multirow[t]{2}{*}{ Phe } & UUU & 794 & 1.33 & \multirow[t]{4}{*}{ Ser } & UCU & 446 & 1.66 \\
\hline & UUC & 396 & 0.67 & & UCC & 261 & 0.97 \\
\hline \multirow[t]{6}{*}{ Leu } & UUA & 757 & 2.08 & & UCA & 336 & 1.25 \\
\hline & UUG & 421 & 1.16 & & UCG & 142 & 0.53 \\
\hline & CUU & 463 & 1.27 & \multirow[t]{4}{*}{ Pro } & $\mathrm{CCU}$ & 335 & 1.55 \\
\hline & CUC & 137 & 0.38 & & $\mathrm{CCC}$ & 190 & 0.88 \\
\hline & CUA & 288 & 0.79 & & CCA & 245 & 1.13 \\
\hline & CUG & 118 & 0.32 & & $\mathrm{CCG}$ & 95 & 0.44 \\
\hline \multirow[t]{3}{*}{ Ile } & AUU & 893 & 1.42 & \multirow[t]{4}{*}{ Thr } & $\mathrm{ACU}$ & 434 & 1.62 \\
\hline & AUC & 354 & 0.56 & & $\mathrm{ACC}$ & 189 & 0.7 \\
\hline & AUA & 638 & 1.02 & & ACA & 343 & 1.28 \\
\hline Met & AUG & 510 & 1 & & $\mathrm{ACG}$ & 108 & 1.4 \\
\hline \multirow[t]{4}{*}{ Val } & GUU & 439 & 1.5 & \multirow[t]{4}{*}{ Ala } & GCU & 506 & 1.75 \\
\hline & GUC & 142 & 0.48 & & GCC & 181 & 0.63 \\
\hline & GUA & 435 & 1.48 & & GCA & 335 & 1.16 \\
\hline & GUG & 157 & 0.54 & & GCG & 136 & 0.47 \\
\hline \multirow[t]{2}{*}{ Tyr } & UAU & 686 & 1.64 & \multirow[t]{2}{*}{ Cys } & UGU & 181 & 1.5 \\
\hline & UAC & 153 & 0.36 & & UGC & 60 & 0.5 \\
\hline \multirow[t]{2}{*}{ Ter } & UAA & 27 & 1.53 & Ter & UGA & 13 & 0.74 \\
\hline & UAG & 13 & 0.74 & $\operatorname{Trp}$ & UGG & 383 & 1 \\
\hline \multirow[t]{2}{*}{ His } & CAU & 408 & 1.59 & \multirow[t]{4}{*}{ Arg } & CGU & 284 & 1.37 \\
\hline & CAC & 106 & 0.41 & & CGC & 80 & 0.39 \\
\hline \multirow[t]{2}{*}{ Gln } & CAA & 571 & 1.5 & & CGA & 278 & 1.34 \\
\hline & CAG & 190 & 0.5 & & CGG & 103 & 0.5 \\
\hline \multirow[t]{2}{*}{ Asn } & AAU & 828 & 1.57 & \multirow[t]{2}{*}{ Ser } & AGU & 348 & 1.29 \\
\hline & $\mathrm{AAC}$ & 226 & 0.43 & & AGC & 81 & 0.3 \\
\hline \multirow[t]{2}{*}{ Lys } & AAA & 848 & 1.51 & \multirow[t]{2}{*}{ Arg } & AGA & 390 & 1.88 \\
\hline & AAG & 273 & 0.49 & & AGG & 110 & 0.53 \\
\hline \multirow[t]{2}{*}{ Asp } & GAU & 692 & 1.6 & \multirow[t]{4}{*}{ Gly } & GGU & 466 & 1.27 \\
\hline & GAC & 174 & 0.4 & & GGC & 166 & 0.45 \\
\hline \multirow[t]{2}{*}{ Glu } & GAA & 856 & 1.51 & & GGA & 586 & 1.6 \\
\hline & GAG & 275 & 0.49 & & GGG & 245 & 0.67 \\
\hline
\end{tabular}

\subsection{Overall Sequence Variation of the Chloroplast Genomes among Species in Lilium}

Preexisting whole plastome data in Lilium provides a basis for comparing genomic variation in the genus [61]. To compare the sequence variation within the genus, alignments among twenty Lilium (including Nomocharis) plastid genome sequences were implemented in the mVISTA program with Shuffle-LAGAN model (Figure 3). Overall, the comparative genomic analysis showed that twenty Lilium (including Nomocharis) chloroplast genomes were relatively conserved. Among the Lilium 
species, the IR region is more conserved than the LSC and SSC regions, similar with studies in other plants $[47,51,61-63]$, and more variation were detected in the intergenic spacers in the LSC and SSC regions. In addition, fewer variations were found in protein coding regions. In the whole chloroplast genome sequences of Lilium species, some highly divergent regions including matK, rpoC2, rps3, ycf2,

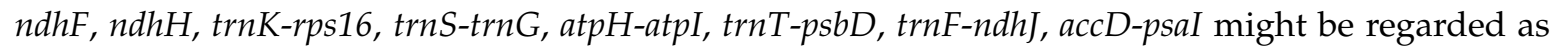
potential molecular markers for Lilium plants. Further work is needed to be implemented to verify whether these regions are suitable as molecular markers for phylogenetic studies of Lilium.
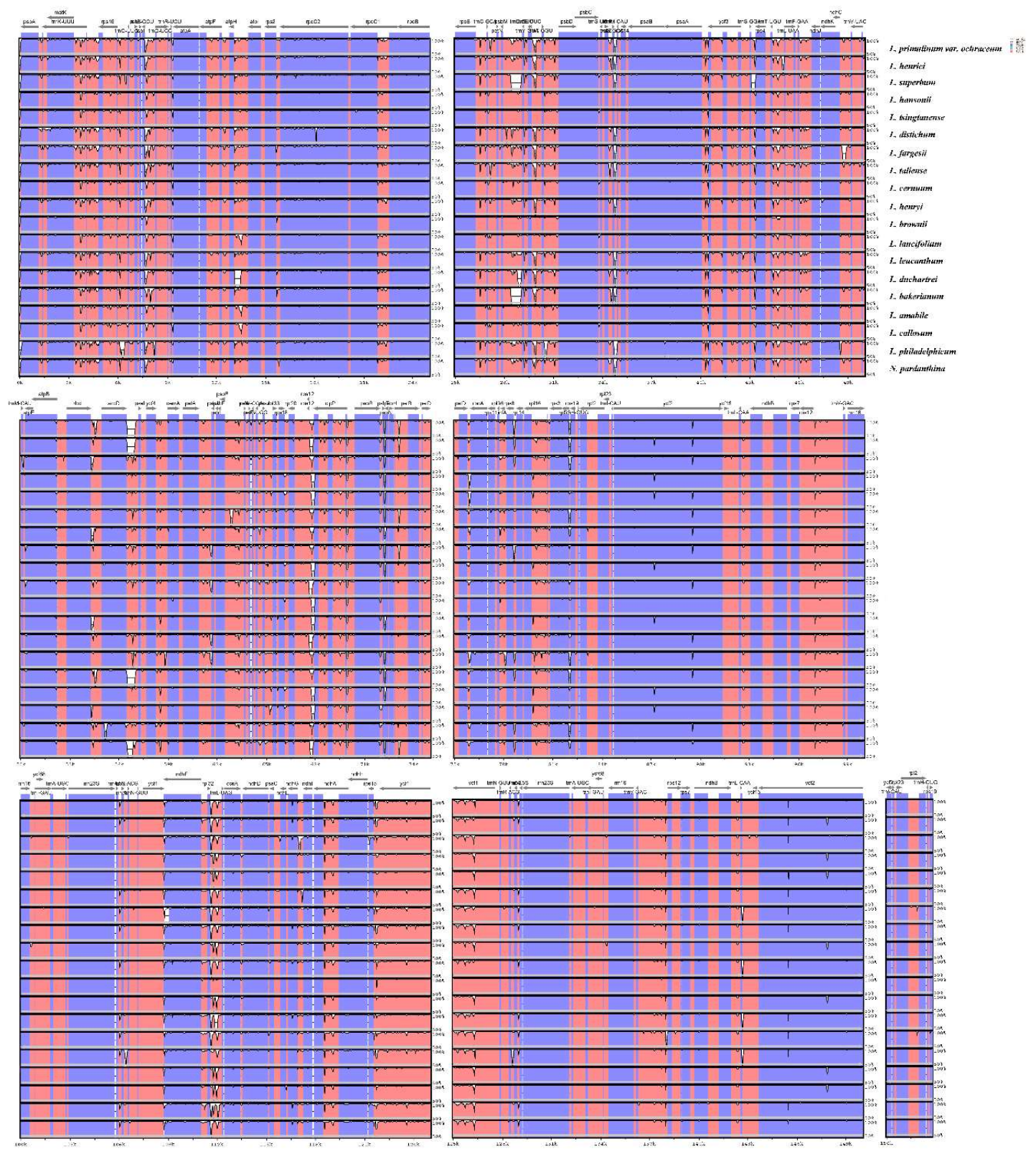

Figure 3. Sequence alignment of twenty Lilium (including Nomocharis) chloroplast genomes, with L. longiflorum as a reference. The y-axis indicates the percent identity between $50 \%$ and $100 \%$. Genome regions colored represent protein coding regions, rRNA coding regions, tRNA coding regions or conserved noncoding sequences (CNS).

The main reason of change in the size of the chloroplast genome is the expansion/contraction of IR regions [64], and the location of the boundaries among the four chloroplast regions is useful for evolutionary studies [62]. The chloroplast genome organization is rather conserved within Lilium. 
The twenty Lilium (including Nomocharis) chloroplast genome sequences range from 151,655 bp (L. bakerianum) to $153,235 \mathrm{bp}$ (L. fargesii), including an LSC region of 81,224-82,542 bp, an SSC region of 17,038-17,620 bp, and a pair of IR regions of 26,394-26,990 bp. The overall GC content of the complete genomes is $36.9-37.1 \%$. There generally are the same gene order in all genomic sequences. We compared the borders of LSC, SSC and IR regions among twenty Lilium (including Nomocharis) plastid genomic sequences (Figure S1) and the IR regions of twenty Lilium (including Nomocharis) chloroplast genomes are conserved.

\subsection{Phylogenetic Analysis}

In the previous reports, the chloroplast genomes are of great significance in the reconstruction of plants phylogenetic relationships and evolutionary history [63-65]. In our study, we constructed a phylogenetic tree using the sequences of the whole chloroplast genomes of twenty-five species in the family Liliaceae, including twenty Lilium (including Nomocharis) species and using five species in Cardiocrinum and Fritillaria as outgroups (Figure 4). All clades were strongly supported, and L. henrici was sister to $N$. pardanthina. The phylogenetic tree indicated that twenty species in Lilium (including Nomocharis) clustered into two groups. One group comprised section Sinomartagon (L. cernuum, L. callosum, L. lancifolium and L. amabile,), Section Martagon (L. hansonii and L. tsingtauense), and Section Leucolirion (L. longiflorum and L. brownie). Another group comprised Section Sinomartagon (L. taliense, L. primulinum var. ochraceum and L. bakerianum), Lilium-Nomocharis (L. henrici and N. pardanthina), Section Pseudolirium (L. philadelphicum), Section Martagon (L. distichum), Section Leucolirion (L. leucanthum and L. henryi), section Sinomartagon (L. duchartrei and L. fargesii), and Section Pseudolirium (L. superbum).

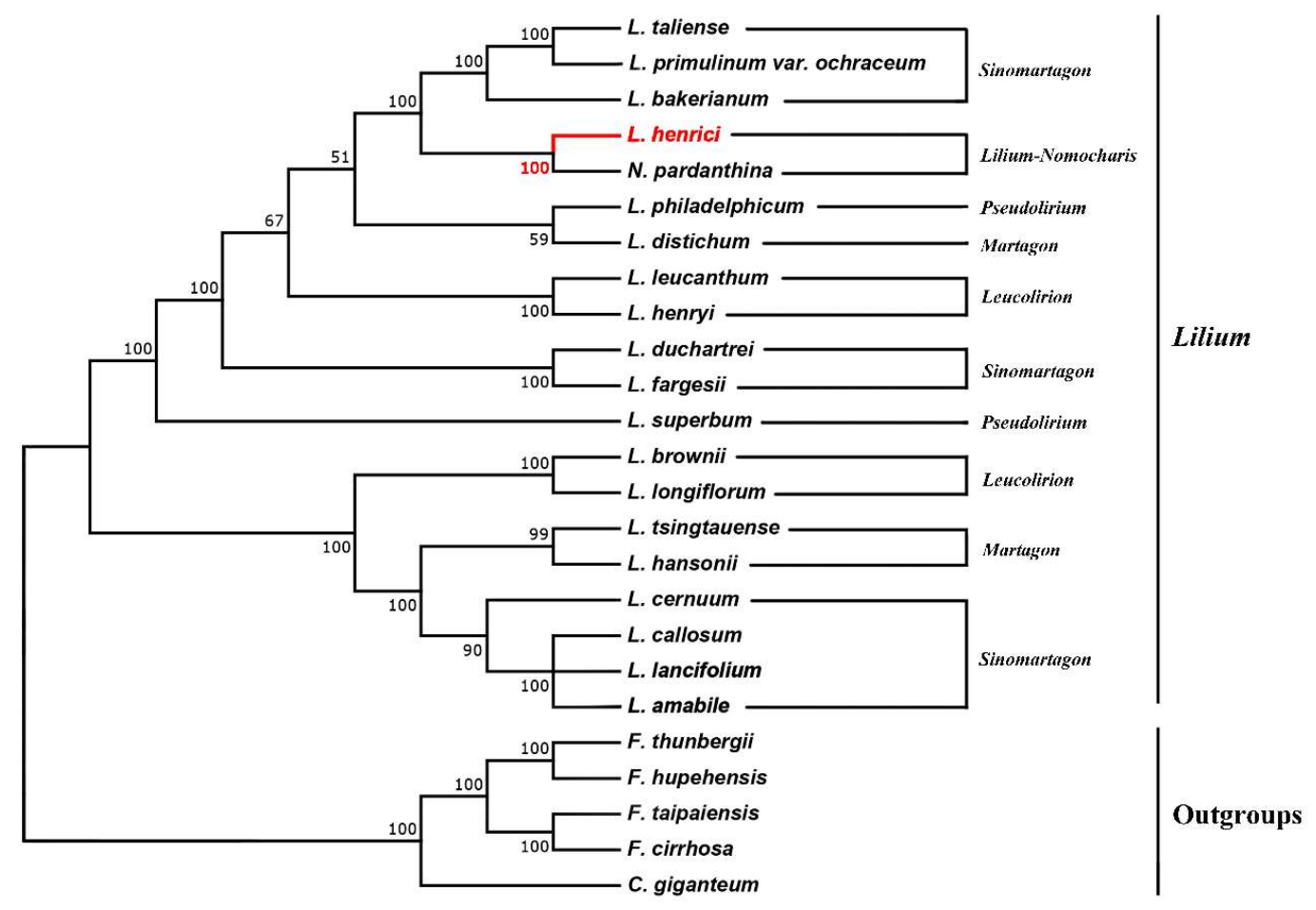

Figure 4. Molecular phylogenetic tree of the family Liliaceae based on the complete chloroplast genomes among 25 species. The tree was constructed using maximum likelihood (ML) algorithm and the GTR + I + G model.

The phylogenetic tree acquired in our study is consistent with previous studies [12,14,39]. The clade Lilium-Nomocharis was highly supported, and this conclusion was already proposed in many studies $[9,12,66]$, and Gao et al. accommodated Nomocharis in Lilium [13]. The sister relationship 
between L. henrici and N. pardanthina is also supported by morphological and cytological evidence: (1) characteristic of inner perianth: sometimes anthocyanin rich [12]; (2) characteristics of karyotype: same basic chromosomal number $(x=12)$; karyotype asymmetry (3A type) [67]. However, we had used only a small number of species in Lilium-Nomocharis clade, other chloroplast genome sequences of species that might be included in this clade should be sequenced as soon as possible.

\section{Conclusions}

We have sequenced the whole chloroplast genome of L. henrici using Illumina sequencing technology for the first time and compared its structure with other Lilium species. The plastid genome of L. henrici exhibits quadripartite structure. Compared with other chloroplast genomes in Lilium, it has similar size, genomic structure and gene order. And the chloroplast genome sequences in Lilium is relatively conserved at the boundaries of the IR regions and the SC regions. By comparing twenty Lilium (including Nomocharis) plastid genome sequences, we obtained 12 highly divergent regions. 51 SSRs were identified in L. henrici. We detected nine common SSRs in twenty Lilium (including Nomocharis) chloroplast genome sequences and these loci might play an important role in the further researches on the genetic structure of the genus Lilium. The research on codon usage of L. henrici shows that some amino acids have obvious codon usage bias and the codon preferences may help us understand the evolution mechanisms of L. henrici more deeply. Reconstructed molecular phylogenetic relationships using 25 complete chloroplast genome sequences in Liliaceae strongly supports the close sister relationship of N. pardanthina and L. henrici. We try to find morphological and cytological evidence to support their close relationship. Other whole chloroplast genome sequences of Lilium-Nomocharis clade need to be sequenced to understand the position of this clade or Nomocharis in the genus Lilium. The genome data obtained in this study will provide a theoretical basis for determinating the phylogenetic relationship of Lilium.

Supplementary Materials: The following are available online. Table S1: CDS used in the codon usage analysis and corresponding GC content, Table S2: Intron and exon information in the chloroplast genome of L. henrici, Table S3: Simple sequence repeats (SSRs) detected in the twenty chloroplast genome sequences of Lilium (including Nomocharis).

Author Contributions: H.-Y.L., Y.Y. and S.-D.Z. conceived the experiments; H.-Y.L. and J.L. collected materials; H.-Y.L., Y.-Q.D. and Z.-X.H. performed the experiments; H.-Y.L. analysed the data and wrote the manuscript. All authors read and approved the final manuscript.

Funding: This research was funded by the National Natural Science Foundation of China [31570198 and 31500188], and the Chinese Ministry of Science and Technology through the "National Science and Technology Infrastructure Platform" project [Grant No. 2005DKA21403-JK].

Conflicts of Interest: The authors declare no conflict of interest.

\section{References}

1. Liang, S.Y.; Tamuram, M.N. Lilium. Flora of China; Science Press: Beijing, China, 2000; Volume 24, pp. 135-149.

2. Munafo, J.P., Jr.; Gianfagna, T.J. Chemistry and biological activity of steroidal glycosides from the Lilium genus. Nat. Prod. Rep. 2014, 32, 454-477. [CrossRef] [PubMed]

3. Van Tuyl, J.M.; Arens, P. Lilium: Breeding history of the modern cultivar assortment. Acta Hortic. 2011, 900, 795-796. [CrossRef]

4. Comber, H.F. A New Classification of Genus Lilium. Lily Year Book; Royal Horticultural Society: London, UK, 1949; Volume 13, pp. 86-105.

5. Nishikawa, T.; Okazaki, K.; Uchino, T.; Arakawa, K.; Nagamine, T. A molecular phylogeny of Lilium in the internal transcribed spacer region of nuclear ribosomal DNA. J. Mol. Evol. 1999, 49, 238-249. [CrossRef] [PubMed]

6. Hayashi, K.; Kawano, S. Molecular systematics of Lilium and allied genera (Liliaceae): Phylogenetic relationships among Lilium and related genera based on the $r b c L$ and matK gene sequence data. Plant Species Biol. 2000, 15, 73-93, Erratum in 2000, 15, 195. [CrossRef] 
7. Nishikawa, T.; Okazaki, K.; Arakawa, K.; Nagamine, T. Phylogenetic Analysis of Section Sinomartagon in Genus Lilium Using Sequences of the Internal Transcribed Spacer Region in Nuclear Ribosomal DNA. Breed. Sci. 2001, 51, 39-46. [CrossRef]

8. Chang, S.L.; Kim, S.C.; Yeau, S.H.; Lee, N.S. Major Lineages of the Genus Lilium (Liliaceae) Based on nrDNA ITS Sequences, with Special Emphasis on the Korean Species. J. Plant Biol. 2011, 54, 159-171.

9. Gao, Y.D.; Harris, A.J.; Zhou, S.D.; He, X.J. Evolutionary events in Lilium (including Nomocharis, Liliaceae) are temporally correlated with orogenies of the Q-T plateau and the Hengduan Mountains. Mol. Phylogenet. Evol. 2013, 68, 443-460. [CrossRef] [PubMed]

10. Gao, Y.D.; Zhou, S.D.; He, X.J. Lilium yapingense (Liliaceae), a New Species from Yunnan, China, and its Systematic Significance Relative to Nomocharis. Ann. Bot. Fenn. 2013, 50, 187-194. [CrossRef]

11. Du, Y.P.; He, H.B.; Wang, Z.X.; Li, S.; Wei, C.; Yuan, X.N.; Cui, Q.; Jia, G.X. Molecular phylogeny and genetic variation in the genus Lilium native to China based on the internal transcribed spacer sequences of nuclear ribosomal DNA. J. Plant Res. 2014, 127, 249-263. [CrossRef] [PubMed]

12. Gao, Y.D.; Harris, A.J.; He, X.J. Morphological and ecological divergence of Lilium and Nomocharis within the Hengduan Mountains and Qinghai-Tibetan Plateau may result from habitat specialization and hybridization. BMC Evol. Biol. 2015, 15, 1-21. [CrossRef] [PubMed]

13. Gao, Y.D.; Gao, X.F. Accommodating Nomocharis in Lilium (Liliaceae). Phytotaxa 2016, 277, 205-210. [CrossRef]

14. Du, Y.; Bi, Y.; Yang, F.; Zhang, M.; Chen, X.; Xue, J.; Zhang, X. Complete chloroplast genome sequences of Lilium: Insights into evolutionary dynamics and phylogenetic analyses. Sci. Rep. 2017, 7, 5751. [CrossRef] [PubMed]

15. Long, Y.; Zhang, J. The conservation and utilization of lily plant resources. J. Plant Resour. Environ. 1998, 7, $40-44$.

16. Lv, S.N.; Zhao, P. The conservation and utilization of lily plant resource. J. Lishui Teach. Coll. 2001, 23, 35-38.

17. Green, B.R. Chloroplast genomes of photosynthetic eukaryotes. Plant J. 2011, 66, 34-44. [CrossRef] [PubMed]

18. Zhang, Y.J.; De-Zhu, L.I. Advances in phylogenomics based on complete chloroplast genomes. Plant Divers. Resour. 2011, 33, 365-375.

19. Lei, W.; Ni, D.; Wang, Y.; Shao, J.; Wang, X.; Yang, D.; Wang, J.; Chen, H.; Liu, C. Intraspecific and heteroplasmic variations, gene losses and inversions in the chloroplast genome of Astragalus membranaceus. Sci. Rep. 2016, 6, 21669. [CrossRef] [PubMed]

20. Parks, M.; Cronn, R.; Liston, A. Increasing phylogenetic resolution at low taxonomic levels using massively parallel sequencing of chloroplast genomes. BMC Biol. 2009, 7, 1-17. [CrossRef] [PubMed]

21. Daniell, H.; Lin, C.S.; Ming, Y.; Chang, W.J. Chloroplast genomes: Diversity, evolution, and applications in genetic engineering. Genome Biol. 2016, 17, 134. [CrossRef] [PubMed]

22. Andrews, S. FastQC: A Quality Control Tool for High Throughput Sequence Data. 2015. Available online: http:/ / www.bioinformatics.babraham.ac.uk/projects/fastqc/ (accessed on 6 October 2011).

23. Luo, R.; Liu, B.; Xie, Y.; Li, Z.; Huang, W.; Yuan, J.; He, G.; Chen, Y.; Pan, Q.; Liu, Y. SOAPdenovo2: An empirically improved memory-efficient short-read de novo assembler. Gigascience 2012, 1, 18. [CrossRef] [PubMed]

24. Kearse, M.; Moir, R.; Wilson, A.; Stoneshavas, S.; Cheung, M.; Sturrock, S.; Buxton, S.; Cooper, A.; Markowitz, S.; Duran, C. Geneious Basic: An integrated and extendable desktop software platform for the organization and analysis of sequence data. Bioinformatics 2012, 28, 1647-1649. [CrossRef] [PubMed]

25. Schattner, P.; Brooks, A.N.; Lowe, T.M. The tRNAscan-SE, snoscan and snoGPS web servers for the detection of tRNAs and snoRNAs. Nucleic Acids Res. 2005, 33, 686-689. [CrossRef] [PubMed]

26. Lohse, M.; Drechsel, O.; Kahlau, S.; Bock, R. Organellar Genome DRAW-A suite of tools for generating physical maps of plastid and mitochondrial genomes and visualizing expression data sets. Nucleic Acids Res. 2013, 41, W575. [CrossRef] [PubMed]

27. MISA-Microsatellite Identification Tool. Available online: http://pgrc.ipk-gatersleben.de/misa/ (accessed on 27 September 2010).

28. Peden, J.F. CodonW. Ph.D. Thesis, University of Nottingham, Nottinghamshire, UK, 1999.

29. Wright, F. The 'effective number of codons' used in a gene. Gene 1990, 87, 23-29. [CrossRef]

30. Yang, Y.; Zhu, J.; Feng, L.; Zhou, T.; Bai, G.; Yang, J.; Zhao, G. Plastid Genome Comparative and Phylogenetic Analyses of the Key Genera in Fagaceae: Highlighting the Effect of Codon Composition Bias in Phylogenetic Inference. Front. Plant Sci. 2018, 9, 82. [CrossRef] [PubMed] 
31. Kim, J.S.; Kim, J.H. Comparative Genome Analysis and Phylogenetic Relationship of Order Liliales Insight from the Complete Plastid Genome Sequences of Two Lilies (Lilium longiflorum and Alstroemeria aurea). PLoS ONE 2013, 8, e68180. [CrossRef] [PubMed]

32. Hwang, Y.J.; Lee, S.C.; Kim, K.; Choi, B.S.; Park, J.Y.; Yang, T.J.; Lim, K.B. The complete chloroplast genome of Lilium distichum Nakai (Liliaceae). DNA Seq. 2016, 27, 4633-4634. [CrossRef] [PubMed]

33. Ji, H.S.; Chang, Y.Y.; Do, H.D.K.; Lee, W.B.; Kim, J.H. The complete chloroplast genome sequence of Lilium tsingtauense Gilg (sect. Martagon, Liliaceae). Mitochondrial DNA Part B Resour. 2016, 1, 318-320.

34. Kim, K.; Hwang, Y.J.; Lee, S.C.; Yang, T.J.; Lim, K.B. The complete chloroplast genome sequence of Lilium hansonii Leichtlin ex D.D.T.Moore. Mitochondrial DNA Part A DNA Mapp. Seq. Anal. 2015, 27, 3678-3679.

35. Du, Y.; Bi, Y.; Chen, X.; Yang, F.; Xue, J.; Zhang, X. The complete chloroplast genome of Lilium cernuum: Genome structure and evolution. Conserv. Genet. Resour. 2016, 8, 375-378. [CrossRef]

36. Bi, Y.; Du, Y.; Chen, X.; Yang, F.; Xue, J.; Zhang, X.; Dong, R. The complete chloroplast genome sequence of Lilium fargesii (Lilium, Liliaceae). Conserv. Genet. Resour. 2016, 8, 419-422. [CrossRef]

37. Zhang, Q.; Bi, Y.; Zhang, M.; Chen, X.; Yang, F.; Xue, J.; Du, Y.; Zhang, X. The complete chloroplast genome of Lilium taliense, an endangered species endemic to China. Conserv. Genet. Resour. 2017, 9, 201-203. [CrossRef]

38. Kim, J.H.; Lee, S.I.; Kim, B.R.; Choi, I.Y.; Ryser, P.; Kim, N.S. Chloroplast genomes of Lilium lancifolium, L. amabile, L. callosum, and L. philadelphicum: Molecular characterization and their use in phylogenetic analysis in the genus Lilium and other allied genera in the order Liliales. PLoS ONE 2017, 12, e0186788. [CrossRef] [PubMed]

39. Liu, H.Y.; Li, J.; Xie, D.F.; He, X.J.; Yu, Y.; Zhou, S.D. The complete chloroplast genome of Nomocharis pardanthina. Mitochondrial DNA Part B 2018, 3, 103-104. [CrossRef]

40. Frazer, K.A.; Pachter, L.; Poliakov, A.; Rubin, E.M.; Dubchak, I. VISTA: Computational tools for comparative genomics. Nucleic Acids Res. 2004, 32, W273-W279. [CrossRef] [PubMed]

41. Katoh, K.; Misawa, K.; Kuma, K.I.; Miyata, T. MAFFT: A novel method for rapid multiple sequence alignment based on fast Fourier transform. Nucleic Acids Res. 2002, 30, 3059-3066. [CrossRef] [PubMed]

42. Capellagutiérrez, S.; Sillamartínez, J.M.; Gabaldón, T. trimAl: A tool for automated alignment trimming in large-scale phylogenetic analyses. Bioinformatics 2009, 25, 1972-1973. [CrossRef] [PubMed]

43. Darriba, D.; Taboada, G.L.; Doallo, R.; Posada, D. jModelTest 2: More models, new heuristics and parallel computing. Nat. Methods 2012, 9, 772. [CrossRef] [PubMed]

44. Kumar, S.; Stecher, G.; Tamura, K. MEGA7: Molecular Evolutionary Genetics Analysis Version 7.0 for Bigger Datasets. Mol. Biol. Evol. 2016, 33, 1870-1874. [CrossRef] [PubMed]

45. Wicke, S.; Schneeweiss, G.M.; Depamphilis, C.W.; Kai, F.M.; Quandt, D. The evolution of the plastid chromosome in land plants: Gene content, gene order, gene function. Plant Mol. Biol. 2011, 76, $273-297$. [CrossRef] [PubMed]

46. Zhu, A.; Guo, W.; Gupta, S.; Fan, W.; Mower, J.P. Evolutionary dynamics of the plastid inverted repeat: The effects of expansion, contraction, and loss on substitution rates. New Phytol. 2016, 209, 1747-1756. [CrossRef] [PubMed]

47. Lu, R.S.; Li, P.; Qiu, Y.X. The Complete Chloroplast Genomes of Three Cardiocrinum (Liliaceae) Species: Comparative Genomic and Phylogenetic Analyses. Front. Plant Sci. 2016, 7, 2054. [CrossRef] [PubMed]

48. Sloan, D.B.; Triant, D.A.; Forrester, N.J.; Bergner, L.M.; Wu, M.; Taylor, D.R. A recurring syndrome of accelerated plastid genome evolution in the angiosperm tribe Sileneae (Caryophyllaceae). Mol. Phylogenet. Evol. 2014, 72, 82-89. [CrossRef] [PubMed]

49. Raman, G.; Park, S.J. Analysis of the Complete Chloroplast Genome of a Medicinal Plant, Dianthus superbus var. longicalyncinus, from a Comparative Genomics Perspective. PLoS ONE 2015, 10, e0141329. [CrossRef] [PubMed]

50. Raubeson, L.A.; Peery, R.; Chumley, T.W.; Dziubek, C.; Fourcade, H.M.; Boore, J.L.; Jansen, R.K. Comparative chloroplast genomics: Analyses including new sequences from the angiosperms Nuphar advena and Ranunculus macranthus. BMC Genom. 2007, 8, 174. [CrossRef] [PubMed]

51. Liu, L.X.; Li, R.; Worth, J.R.P.; Li, X.; Li, P.; Cameron, K.M.; Fu, C.X. The Complete Chloroplast Genome of Chinese Bayberry (Morella rubra, Myricaceae): Implications for Understanding the Evolution of Fagales. Front. Plant Sci. 2017, 8, 968. [CrossRef] [PubMed]

52. Bi, Y.; Zhang, M.F.; Xue, J.; Dong, R.; Du, Y.P.; Zhang, X.H. Chloroplast genomic resources for phylogeny and DNA barcoding: A case study on Fritillaria. Sci. Rep. 2018, 8, 1184. [CrossRef] [PubMed] 
53. Li, P.; Lu, R.S.; Xu, W.Q.; Ohitoma, T.; Cai, M.Q.; Qiu, Y.X.; Cameron, K.M.; Fu, C.X. Comparative Genomics and Phylogenomics of East Asian Tulips (Amana, Liliaceae). Front. Plant Sci. 2017, 8, 451. [CrossRef] [PubMed]

54. Park, I.; Kim, W.J.; Yeo, S.M.; Choi, G.; Kang, Y.M.; Piao, R.; Moon, B.C. The Complete Chloroplast Genome Sequences of Fritillaria ussuriensis Maxim. and Fritillaria cirrhosa D. Don, and Comparative Analysis with Other Fritillaria Species. Molecules 2017, 22, 982. [CrossRef] [PubMed]

55. Wang, Y.; Zhan, D.F.; Jia, X.; Mei, W.L.; Dai, H.F.; Chen, X.T.; Peng, S.Q. Complete Chloroplast Genome Sequence of Aquilaria sinensis (Lour.) Gilg and Evolution Analysis within the Malvales Order. Front. Plant Sci. 2016, 7, 280. [CrossRef] [PubMed]

56. Zhang, Y.; Du, L.; Ao, L.; Chen, J.; Li, W.; Hu, W.; Wei, Z.; Kim, K.; Lee, S.C.; Yang, T.J. The Complete Chloroplast Genome Sequences of Five Epimedium Species: Lights into Phylogenetic and Taxonomic Analyses. Front. Plant Sci. 2016, 7, 306. [CrossRef] [PubMed]

57. Zhao, Y.; Yin, J.; Guo, H.; Zhang, Y.; Xiao, W.; Sun, C.; Wu, J.; Qu, X.; Yu, J.; Wang, X. The complete chloroplast genome provides insight into the evolution and polymorphism of Panax ginseng. Front. Plant Sci. 2015, 5, 696. [CrossRef] [PubMed]

58. Huang, H.; Shi, C.; Liu, Y.; Mao, S.Y.; Gao, L.Z. Thirteen Camellia chloroplast genome sequences determined by high-throughput sequencing: Genome structure and phylogenetic relationships. BMC Evol. Biol. 2014, 14, 151. [CrossRef] [PubMed]

59. Sharp, P.M.; Li, W.H. An evolutionary perspective on synonymous codon usage in unicellular organisms. J. Mol. Evol. 1986, 24, 28-38. [CrossRef] [PubMed]

60. Morton, B.R. The Role of Context-Dependent Mutations in Generating Compositional and Codon Usage Bias in Grass Chloroplast DNA. J. Mol. Evol. 2003, 56, 616-629. [CrossRef] [PubMed]

61. Liu, L.; Wang, Y.; He, P.; Li, P.; Lee, J.; Soltis, D.E.; Fu, C. Chloroplast genome analyses and genomic resource development for epilithic sister genera Oresitrophe and Mukdenia (Saxifragaceae), using genome skimming data. BMC Genom. 2018, 19, 235. [CrossRef] [PubMed]

62. Menezes, A.P.A.; Resendemoreira, L.C.; Buzatti, R.S.O.; Nazareno, A.G.; Carlsen, M.; Lobo, F.P.; Kalapothakis, E.; Lovato, M.B. Chloroplast genomes of Byrsonima species (Malpighiaceae): Comparative analysis and screening of high divergence sequences. Sci. Rep. 2018, 8, 2210. [CrossRef] [PubMed]

63. Chaney, L.; Mangelson, R.; Ramaraj, T.; Jellen, E.N.; Maughan, P.J. The complete chloroplast genome sequences for four Amaranthus species (Amaranthaceae). Appl. Plant Sci. 2016, 4, 1600063. [CrossRef] [PubMed]

64. Hong, S.Y.; Cheon, K.S.; Yoo, K.O.; Lee, H.O.; Cho, K.; Suh, J.T.; Kim, S.J.; Nam, J.H.; Sohn, H.B.; Kim, Y.H. Complete Chloroplast Genome Sequences and Comparative Analysis of Chenopodium quinoa and C. album. Front. Plant Sci. 2017, 8, 1696. [CrossRef] [PubMed]

65. Gitzendanner, M.A.; Soltis, P.S.; Wong, G.K.-S.; Ruhfel, B.R.; Soltis, D.E. Plastid phylogenomic analysis of green plants: A billion years of evolutionary history. Am. J. Bot. 2018, 105, 291-301. [CrossRef] [PubMed]

66. Peruzzi, L.; Leitch, I.J.; Caparelli, K.F. Chromosome diversity and evolution in Liliaceae. Ann. Bot. 2009, 103, 459-475. [CrossRef] [PubMed]

67. Wang, L.; Gu, Z.J.; Gong, X.; Xiao, T.J. A cytological study of fifteen species in six genera of Liliaceae from Yunnan. Acta Phytotaxon. Sin. 1993, 31, 549-559.

Sample Availability: Sequence data of Lilium henrici has been deposited into GenBank and are available from the authors.

(C) 2018 by the authors. Licensee MDPI, Basel, Switzerland. This article is an open access article distributed under the terms and conditions of the Creative Commons Attribution (CC BY) license (http://creativecommons.org/licenses/by/4.0/). 